[This is an Accepted Manuscript of an article published by Taylor \& Francis in CRITICAL STUDIES ON SECURITY on 14 November 2019, available online:

https://www.tandfonline.com/doi/full/10.1080/21624887.2019.1690861.]

\title{
The Political Production of Ethical War: Rethinking the Ethics/Politics Nexus with Laclau $^{1}$
}

\section{Frank A. Stengel}

Abstract

Taking Maja Zehfuss's War $\mathcal{E}$ the Politics of Ethics as a starting point, this paper thinks through the ethics/politics nexus from the perspective of "Essex School" poststructuralist discourse theory. Specifically, it asks how ethics - or, rather, morality, the temporary, contingent and context-dependent normative framework that regulates what is commonly seen as good or bad within a given society - is produced. From a discourse theoretical perspective, notions of the moral good are the result of political struggles over meaning. Here Laclau and Mouffe's conception of hegemony can provide significant insight into how this process works, that is, how some claims about what is morally right become widely accepted as the (only) right thing to do while others fail to do so. The paper illustrates the theoretical argument with a brief case study of the changing articulation of the threat and use of military force in the German security discourse after unification. This case is of particular interest because Germany's allegedly deeply engrained antimilitarist culture should, from a constructivist perspective at least, stand in the way of any arguments about ethical war ever becoming accepted. Nevertheless, this is precisely what happened.

Keywords: ethics; morality; war; politics; the political; discourse; Ernesto Laclau; Chantal Mouffe; Critical Security Studies; German foreign policy; out-of-area debate

\footnotetext{
${ }^{1}$ I would like to thank Nisha Shah and Dirk Nabers for the invitation to contribute to this symposium. I am also grateful to the participants in the workshop that is the basis for this symposium as well as two anonymous reviewers for helpful comments on earlier versions of this paper.
} 


\section{Introduction}

In her highly insightful and stimulating new book War and the Politics of Ethics, Maja Zehfuss (2018) explores the relationship between ethical arguments and war from the perspective of Jacques Derrida. Going against the grain of the majority of current theorizing on the ethics of war, Zehfuss argues that rather than constraining violence in war, ethical arguments broadly understood as arguments referring to notions of 'the good' - in fact often contribute to the legitimation of war and even increased violence. ${ }^{2}$ In pointing out that ethical statements and the use of military violence do not necessarily have to be opposed, Zehfuss makes an important argument that is not only theoretically relevant but also of practical import because it cautions against the assumption that adhering to certain moral principles (e.g., Just War Theory) will automatically bring about desired results (less violence).

This article engages Zehfuss's argument from the perspective of the poststructuralist discourse theory of the so-called "Essex School," as advanced by Ernesto Laclau and Chantal Mouffe (2001). ${ }^{3}$ Given that Laclau (1990) explicitly draws on Derrida, it will not come as a surprise that I find myself largely in agreement with Zehfuss's argument. Thus, rather than antithetical I see a discourse theoretical perspective as complementary to a Derridean approach. Bringing Derrida to bear on questions of ethics and war reveals the fluidity, context-dependence and contingency of the (at times contradictory) relationship between the

${ }^{2}$ I am using the term 'violence' here instead of 'force' to minimize the risk of inadvertently whitewashing the violence involved also in allegedly 'ethical' war (Thomas 2011). Moreover, in contrast to in particular quantitative peace and conflict research, Zehfuss understands war broadly referring to all kinds of military violence, not necessarily that limited to a certain number of battle deaths. Since her (and my) focus is on the legitimation of any military violence, not necessarily only full-blown war, we can neglect these definitional issues here.

${ }^{3}$ There is a small but growing literature drawing on discourse theory in IR. Due to lack of space, I cannot discuss these extensively here, but see for example Herschinger (2011), Solomon (2014), Nabers (2015), Rothe (2015), Eberle (2019) and, most recently, the contributions to issue 2/2019 of New Political Science. 
two. What Zehfuss clearly shows is that normative principles can either weaken or strengthen the case for the use of military violence, depending on how they are articulated in discourse. A discourse theoretical perspective can supplement this perspective by providing a theoretical account of the process through which notions of morality change, that is, how certain claims of what is good become accepted while competing arguments fail. With respect to ethical war more specifically, Laclau and Mouffe provide insights into how military violence becomes articulated as morally unacceptable in one context and necessary in another as a result of what they call discursive hegemony. Aside from studies concerned with the ethics of war and the legitimation of military violence (e.g., Nuñez-Mietz 2018), this argument should be of interest also to scholars concerned with norm dynamics (see in particular Renner 2013).

In order to illustrate the theoretical argument, the paper provides a brief case study of the changing morality of military force in the context of the German "out-of-area debate" of the 1990s (Baumann and Hellmann 2001; Dalgaard-Nielsen 2006; Longhurst 2004). The German case is particularly interesting because the country is commonly said to have a strong antimilitarist culture that manifests itself as an "extraordinary reluctance to become actively involved in international military security affairs" (Berger 1998, 1). With respecrt to ethical war, then, Germany functions as a "crucial" case (Eckstein 1975). Not only does the country share the normative principles Zehfuss discusses with respect to the West as a whole, but due to its antimilitarist culture arguments in favor of ethical war should have more difficulties gaining acceptance in Germany than elsewhere. In spite of that, Germany has since the 1990s continuously explanded its participation in military operations abroad, including in combat operations, which provides an intertesting puzzle (see also Zehfuss 2002, 2007). 
The paper proceeds as follows. I begin with a reconstruction of how "politics" and "ethics" are understood in Zehfuss's book. Then I contrast Zehfuss's understanding of the relationship between ethics and politics with a discourse theoretical reading and discuss what an Essex School perspective can add to our understanding of ethics, politics and war. The subsequent section illustrates the theoretical argument using the German out-of-area debate as an illustration.

\section{Ethics and Politics in War and the Politics of Ethics}

The starting point of War and the Politics of Ethics is a perceived increase in arguments in favor of what Zehfuss calls "ethical war", i.e., war that is (portrayed as) waged for the purpose of "making the world a better place for others" (Zehfuss 2018, 10, 2). This is reflected in policy discourses on "humanitarian" intervention and the Responsibility to Protect (R2P), and it finds its most prominent theoretical expression in just war theory (but see O'Driscoll, this issue). In this context, ethical arguments serve two purposes: to help establish (1) under which circumstances war might be justified or even morally required (ius ad bello) and (2) how it should be waged to remain morally acceptable (ius in bello). From a just war perspective, any endurance of high levels of violence, and in particular civilian deaths, is due to an insufficient implementation of adequate rules.

Zehfuss brushes this literature against the grain, arguing that this is actually not at all what is happening. Contrary to claims by both practitioners and just war scholars, she argues that ethical arguments do not in fact constrain military violence but, quite to the contrary, work “to legitimize war and even to enhance its violence" (Zehfuss 2018, 9). Drawing on Derridean concepts like aporia and the supplement, Zehfuss explores the connection between ethics, politics and war in detail and shows how the relationship is much more complicated and contradictory than one would expect. 
In order to contrast Zehfuss's argument with a discourse theoretical one, in the following I will discuss Zehfuss's understanding of ethics, politics and their relationship in more detail. I find that both, "ethics" and "politics" are understood in (at least) two different ways throughout the text. One is the understanding in the texts Zehfuss critically engages with, the other is based on her reading of Derrida (see table 1 below).

Table 1. Ethics and politics in War and the Politics of Ethics

$<$ INSERT TABLE 1 HERE $>$

Source: author's illustration

The first understanding of ethics is concerned with questions of the "morally good" (Zehfuss 2018, 10f, 50). What is meant here is not the possibility of ethical statements as such (as in metaethics, see Sayre-McCord 2012) but the specific contents according to which certain actions are deemed good (e.g., helping people) or bad (e.g., theft) in a given society. This is what is commonly referred to as morality or the normative order(s) of society. I will refer to this as ethics-as-morality.

The second usage of ethics is more broadly concerned with theoretical debate about moral principles or arguments. Here, ethics refers to abstract discussion of "ideas about how we ought to act towards others" (Fagan quoted in Zehfuss 2018, 11), detached from specific contents (i.e., morality). This is, for lack of a better term, what I call ethics-as-moral-theory. Zehfuss only briefly touches upon this because her primary interest is in how people use specific ethical arguments with respect to war. 
The third meaning of ethics Zehfuss develops on the basis of Derrida's notion of aporia. I refer to this as ethics-as-decision. For Derrida, ethics only comes into play when people encounter an aporia, a situation in which no single, umambiguous "right way forward" (Zehfuss 2007, 262) exists because none of the available options would "satisfy all rules, principles, and obligations at the same time" (Zehfuss 2018, 46). It is only in these situations, according to Derrida, that ethics comes into play because only in these situations it is not self-evidently clear what to do and actors are forced to make a decision between imperfect options. Moreover, it is only in the moment when the subject encounters an aporia that we can legitimately talk about the subject being responsible for her decision because only a decision outside of the "rules of ethics" is a decision in any meaningful sense (Zehfuss 2018, 47). ${ }^{4}$ The question of "humanitarian" intervention presents exactly such an aporia because both military intervention and abstinence could lead to the injury and/or death of innocents. Contrary to advocates of just war theory, Zehfuss $(2018,4)$ claims that this tension cannot ever be resolved.

Let us move on to politics, which, as a signifier, also refers to more than one signified in Zehfuss's book (see table 1 above). On the level of the discourse under investigation, politics refers to the realm of "the possible" (Zehfuss 2018, 50). This notion of politics, which I will call politics-as-the-possible, is opposed to ethics-as-morality: “One is concerned with potential altruism, while the other takes selfishness as a fact of life" (Zehfuss 2018, 50). While ethics is concerned with the question of what would be morally right to do in a given situation, independent of any considerations of, say, feasibility, potential costs or political

\footnotetext{
${ }^{4}$ Here, Zehfuss is referring to ethics-as-morality.
} 
calculations, politics is primarily concerned with the latter, the, as Zehfuss $(2018,40)$ puts is, "grubby reality of what is".

The second understanding of politics refers to the power-laden struggles involved in producing ethics-as-morality. I will call this politics-as-struggle. This is what Zehfuss means when she speaks about "the politics of ethics" or "the politics of war" (Zehfuss 2018, 9, ch. 6) - the discursive struggles as a result of which certain articulations establish themselves as morally 'right' or 'the truth'. This also means that politics-as-the-possible is equally a result of politics-as-struggle because what is deemed (im)possible, (in)adequate or (un)feasible in a given situation is as much subject to interpretation as is the right thing to do.

In a nutshell, Zehfuss's argument with respect to ethics and politics is that ethics-asmorality and politics-as-the-possible are constructed, in the discourse concerned with the ethics of war, as two separate realms: "ethics is considered in some way prior to - or at least separate from - politics, untouched by the grubby realities of the world" (Zehfuss 2018, 51). Based on Derrida's notion of the supplement, Zehfuss reveals this to be a false dichotomy, arguing instead that notions of "the good" are "always already impacted by what is considered possible" (Zehfuss 2018, 40,12). However, the separation of politics and ethics has real-world consequences: assuming that ethical principles can guide policy action in such a way that war can be used for the good distracts from unintended consequences that are beyond decision-makers' control. The result is that rather than constraining violence, ethical arguments contribute to its increase. For claiming that stricter ethical rules will solve the problem then only works to legitimize military violence by making it appear as if war could become 'clean' if only the right rules were found and/or rigorously applied, thus making it appear to be a valid option that is not always already ethically problematic. 


\section{The Political Production of Ethics: How (Ethics-as-)Morality Changes}

As noted at the outset of this article, discourse theory's primary added value is that it provides a theoretical framework with which to explain how certain notions of the good come accepted in political struggles, while others fail. In the following, I will give a brief overview of how changing notions of morality can be explained from a discourse theoretical perspective. Given the limited scope of this article, my discussion of discourse theory will somewhat narrowly focus on understanding how (ethics-as-)morality changes and only briefly touching upon Laclau and Mouffe's rather elaborate social ontology (for a more detailed discussion, see Stengel and Nabers 2019).

The most basic point to make about ethical war from a discourse theoretical perspective is that ethics-as-morality is produced in on-going discursive struggles - an argument that Zehfuss herself makes when she talks about the "politics of ethics" (politicsas-struggle). This is part of a larger argument that Laclau and Mouffe make about the ontology of the social. For them, the social - the rules, norms, values, cultures, identities, institutions, class structures, gender roles and so on that make society more than the sum total of individual human bodies - is produced in (not just mediated through) discourse (Laclau 2005, 68). ${ }^{5}$ Discourses here are understood in this context as "relational systems of signification" \{Torfing, $2005 \# 2564 @ 14\}$, which is a fancy way of saying that the meaning of its individual elements (e.g., specific words like 'dog' but also of social practices like shaking someone's hand as a form of greeting) is created through how they are related to other discursive elements in a specific context \{Laclau, 2001 \#10296@106, 107;Laclau, 2005

\footnotetext{
${ }^{5}$ Very similar to critical IR, Laclau insists that there is no such thing as a "neutral factual description" of reality (Laclau 2014c, 134), and that in attempting to describe social reality, we are in fact intervening.
} 
\#5699@69, 69\}.6 The way discourses are produced and change is through articulation, "any practice establishing a relation among elements such that their identity is modified as a result of the articulatory practice" (Laclau and Mouffe 2001, 105).

There is in principle a larger story to be told here about what Laclau in his later work has referred to as "dislocation" (Laclau 1990, 43). According to Laclau and Mouffe, and this will be familiar from IR poststructuralim, conceptualize any discursive structures as marked by chronic disruption or "lack" (Laclau 1990, 43).7 Any and all discourses are unavoidably partial, incomplete, fluid and only temporarily fixated, and as a consequence vulnerable to rearticulation. No discourse can ever fully fix meaning. For example, 'freedom' means something entirely different in a Marxist discourse (freedom from wage labor) than in a neoliberal discourse (freedom to choose) (Stengel forthcoming, ch. 1). Neither discourse manages to monopolize what "freedom" really means, so both understandings remain vulnerable to contestation. Because the social as such is discursively produced, dislocation means that also norms, values, identities, are always partial, incomplete, temproary, fluid, and open to (re)interpretation and contestation, as Zehfuss's discussion of aporia makes clear.

Let us get back to the question posed at the outset, namely of how certain articulations, including arguments that some policy option is morally superior to the available alternatives, manage to become widely accepted. In principle, which discourses prevail in discursive struggles over meaning and establish themselves as taken for granted

\footnotetext{
${ }^{6}$ If this seems familiar, that is because IR poststructuralist (often explicitly drawing on Laclau and Mouffe) studies usually also emphasize the differential construction of meaning.
}

7 There is an extended, more complicated argument to be made here about antagonism, the (possibility of) limits of discursive systems, etc., but I will leave it aside here for practical reasons (see Laclau 1990, 1996). 
discursive orders is a result of discursive hegemony. ${ }^{8}$ Hegemony refers to the process in which particularities (particular articulations or discourses) establish themselves as universals (the truth, the common good, etc.) (Laclau 2005, 70; Nabers 2015, 72).

The chance of success of a given particular hegemonic project (an attempt to establish a certain discourse or interpretation as dominant) depends on a number of factors. Hegemony begins with the dislocation of a dominant order by events it cannot domesticate (like mainstream IR theory could not explain the end of the Cold War), and as a consequence, one fundamental, if somewhat trivial, condition is that any new project has to hold the promise to be able to avoid past mistakes. At the same time, the project also needs to be credible against the background of sedimented discursive practices, that is, vis-à-vis what is commonly held to be true and morally right. Thus, discourses are never created from scratch but are usually the result of a combination of old and new elements, and a hegemonic project can gain credibility by actively incorporating sedimented discursive practices. To give but one example, arguments in favour of military operations often draw on gendered and racialized representations (familiar from established gender and colonial discourses) through, among others, the valorization of masculine coded characteristics like activity and strength and simultaneous devaluation of feminine coded characteristics like passivity ('doing nothing'), weakness and so on; the gendered positioning of different subjects (soldiers, citizens, 'local' populations) and the construction of the non-Western Other as in need of Western help (see, e.g., Chandra 2013; Doty 1996; Hooper 2001; Hutchings 2008, this issue; Young 2003; Inayatullah 2014; Peterson 2010).

\footnotetext{
${ }^{8}$ See Stengel and Nabers (2019) for a more detailed summary.
} 
In addition three "design features" (Stengel 2019, 304) can further strengthen a project's chance of success. Hegemony is essentially about the formation of a unified movement, and one big part of that is, first, to claim that certain political demands (e.g., for peace, security, welfare, etc.) are in fact not disparate or even contradictory but actually go hand in hand, that they are equivalent. Second, a project has to clearly identify an obstacle standing in the way of the realization of these demands. This radical or antagonistic Other is blamed for the various demands not being fulfilled, which is also what makes the latter seem equivalent (in their joint opposition to the Other). Third, a project can increase its appeal by providing an empty signifier, a demand (for instance, 'freedom') that empties itself from its particular content to such an extent that it can become a symbol with which different social actors can associate their demands (Laclau and Mouffe 2001; Laclau 1990, 1996, 2005, 2012).

To be sure, the presence of the above listed elements does not guarantee that a project comes to be accepted; that depends on whether subjects identify with it. Importantly, though, the subject's decision is itself not determined by the structure. Indeed, because the structure is dislocated, the subject's decision takes place under the condition of undecidability, i.e., in a situation of aporia in which the discursive structure does not outline a clear way forward. For Laclau, a decision is only a real decision if it is radical in the sense that it "cannot appeal to anything in the social order that would operate as its ground (otherwise it would not be radical)" (Laclau 1994, 4). It is in this moment that Laclau locates politics and the political. ${ }^{9}$ Politics for Laclau is "the realm of the decision" (Critchley 2004, 113; see also Norval 2004).

\footnotetext{
${ }^{9}$ Here one can distinguish between the political as an ontological horizon and politics as the ensemble of concrete decisions made at the ontic level (Laclau 1994, 2012; Nabers 2015).
} 
This brings us back to Laclau's notion of ethics. For not only is the realm of the decision where politics is located, but it is also where ethics comes into play (here Laclau and Derrida/Zehfuss converge). Here it is important to revisit Laclau's distinction between ethics(-as-decision) and (ethics-as-)morality (see table 2 below).

Table 2. Ethics and morality in Laclau

$<$ INSERT TABLE 2 HERE $>$

Source: author's illustration based on Critchley (2004), Laclau (2014e) and Nabers (2015)

Ethics, or the ethical, ${ }^{10}$ in Laclau is reserved not for specific notions of morality but for the much more general requirement for the subject to identify with a normative order, i.e., to make a decision which potential action is the morally right one in a given situation. As noted above, the subject's decision is not determined by the structure but emerges "ex nihilo" (Laclau 2014b, 201, italics in original). Only if the subject is left "entirely guideless" (Laclau 2014d, 51) can we speak about a moral engagement and are moving in the realm of ethics. Ethics requires a "radical investment" in which the subject makes a decision to identify with a specific normative order or argument at the expense of competing ones (ibid.).

Distinct from ethics is what Laclau $(2000,81$, italics removed) refers to as morality or "the normative," that is, the "normative order" (Laclau 2004, 121) or the "ensemble of moral norms" of a given society at the ontic level (Laclau 2014b, 181). This is what I have referred to as ethics-as-morality above, and it includes, for instance, the question of whether and under

\footnotetext{
${ }^{10}$ I use here ethics and the ethical interchangeably. As opposed to that, Nabers (2015) draws the line between the ethical as an ontological horizon and ethics/morality as ontic content(s).
} 
which circumstances war is morally acceptable. As opposed to ethics, morality is part of the social and as such the context-dependent, contingent and temporary result of on-going articulatory practices. Through the subject's radical decision, a particular normative order comes to symbolize, to incarnate, the ethical as an ontological horizon (Laclau 2000, 81). What this means, essentially, is that one particular articulation of what is 'good' comes to be accepted as the self-evident, obvious, only, universally valid notion of the good, while alternatives are marginalized.

It is important to note that this is an ideological operation because a particular (one interpretation of what is good) passes itself off as a universal (the common good as such). Ideology for Laclau (2014a) refers to this moment of closure. It is here where the reason for the failure of the ethics(-as-morality) of war lies. The root of this failure is that reality cannot be fully represented - as Zehfuss's discussion of unintended consequences beyond our control demonstrates. Creating the promise that specific ethical rules and principles can solve the problem of the ethics of war if only the right ones were to be found is ideological: it claims universality where there can only be particularity. At the same time, from a Laclauian perspective this ideological moment cannot be escaped either. Since the ethical itself has no content, the only way to (temporarily) represent it is through a particular morality (Laclau 2014d, 51). As a consequence, as any representation is unavoidably ideological (Laclau 2014a, $17 f)$.

\section{Changing Morality and the Possibility of War in the German Out-of-Area Debate}

As has been highlighted in particular by constructivist studies of German foreign policy (Berger 1998; Harnisch and Maull 2001; Maull 2007), military operations used to be 
seen not only as unconstitutional ${ }^{11}$ but also as unacceptable from an ethical point of view. Indeed, one of the major lessons drawn from Germany's aggressive and authoritarian past (in addition to a firm rejection of any special paths) was that Germany should never again be the source of war (see the discussion in Zehfuss 2002, 2007). In line with that, the role of the Bundeswehr, the German armed forces, was strictly limited to conventional deterrence within German borders. Indeed, the Bundeswehr's purpose was articulated in explicit delineation form its predecessors, the Imperial German Army and Navy as well as the National Socialists' Wehrmacht. While the latter were intended to wage war, the Bundeswehr's purpose was the exact opposite - to prevent war from ever occurring (Zehfuss 2007, 4). For instance, in October 1989, Defense Minister Gerhard Stoltenberg's made clear that:
"All preceding armies were above all intended [...] to wage war. The Bundeswehr is the first conscript army in a German democracy. It gains its political rational and moral justification from the mission to prevent war and to preserve peace and freedom" (Stoltenberg, 11/171, 26 October 1989: 12857, emphasis added).

Because its purpose was to prevent war from ever occurring by keeping up a conventional deterrent, the Bundeswehr was to be understood as an "army of peace" (Friedensarmee) (Biehle, 11/182, 7 December 1989: 14008). Thus, during the Cold War, prevalent notions of (ethics-as-)morality precluded the use or even threat of force.

This understanding of the morality of military violence, and its relationship to peace as a policy goal changed during the out-of-area debate of the 1990s. This debate emerged in the context of what appeared to be new conflicts after the end of the Cold War, most notably

\footnotetext{
11 That changed only with the Federal Constitutional Court ruling in 1994 (Philippi 1997).
} 
the Iraqi invasion of Kuwait and the civil wars in Somalia and Yugoslavia. ${ }^{12}$ The international response to this lack of peace was to undertake military interventions of various kinds (e.g. Operation Desert Storm, the intervention in Somalia or the series of interventions in former Yugoslavia), and with it Germany faced demands for contributions to these operations. ${ }^{13}$ In the German security discourse, these demands were championed mainly by members of the conservative-liberal ruling coalition, who claimed that Germany faced international expectations from its allies and partners. As a consequence, sedimented practices of antimilitarism (including moral convictions that military violence was always wrong) on one hand and Western integration and multilateralism on the other, previously considered equivalent, increasingly came in conflict. Zehfuss aptly sums up the dilemma faced by German policymakers:

“The FRG could take part in international military operations and thereby, on the one hand, confirm its integration with the West and therefore its overcoming of the Nazi past, whilst, on the other hand, making use of its military beyond defence and therefore recalling the militarist practices of the Nazi state" (Zehfuss 2002, 209).

As a result, discursive struggles emerged to rearticulate the old order in such a way that it could provide guidance under what was said to be radically altered international

\footnotetext{
${ }^{12}$ To be precise, the Cold War security order was also dislocated by Cold War détente and the Soviet demise, which put the Bundeswehr's raison d'être in doubt. Since the focus here is on the rearticulation of the morality of military violence, I will limit my discussion to the latter.

${ }^{13}$ This is not to say that troop requests emerged out of nowhere at the end of the Cold War. For instance, in the context of the Vietnam War the U.S. had already requested troops from Germany (Philippi 1997, 60). However, before the end of the Cold War, the consensus had been that out-of-area operations were unconstitutional.
} 
circumstances and to find a way out of the moral aporia that events like the Yugoslav wars presented.

Particularly relevant in this context is what I call, for convenience's sake, the project of Germany's new international responsibility, which sought, ultimately successfully, to make out-of-area operations possible. ${ }^{14}$ The project emerged in the early 1990s in the context of the Iraqi invasion of Kuwait. Although Germany did not itself commit troops to Operation Desert Storm (if however significant financial resources), the mission to drive Iraqi forces out of Kuwait, members of the ruling conservative-liberal coalition began to argue for German participation in multinational operations. At the heart of the argument were normative considerations of German responsibility. For instance, Chancellor Helmut Kohl argued that the "[f]reedom [gained through German unification] and [the acceptance of Germany's international] responsibility inseparably belong together" (Kohl, 12/5, 30 January 1991: 67). Because of its "increased responsibility" after unification, Germany's allies expected that the country "fulfil this new role" (Kohl, 12/5, 30 January 1991: 69), mainly through participation in peace operations. As Kohl continued, Germany's allies “correctly expected that Germany intensify its commitment" in the field of "peacekeeping in the world" (Kohl, 12/5, 30 January 1991: 90), and to make that possible, the "constitutional foundations" should be "clarified" (Kohl, 12/5, 30 January 1991: 90).

In the following years, elements of the Cold War order, in particular military operations, were rearticulated in such a way as to make participation in military operations possible. Before unification, the use of military means, and in particular military force, was closely associated with Germany's authoritarian and aggressive past, i.e. Imperial and Nazi

\footnotetext{
${ }^{14}$ For a more detailed discussion of the project, see Stengel (forthcoming, ch. 3).
} 
Germany, and deemed immoral, while military reticence (in addition to multilateralism and Western integration) was seen as the proper lesson of history and the morally 'right thing to do'. During the 1990s, military means was detached from its specific position within the Cold War security order with its close connection to aggression, tyranny, hyper-nationalism, international isolation and deviance, and more generally notions of moral reprehensibility. On the flipside, military reticence narrowly understood as a complete rejection of military operations under any circumstances also became detached from its close connection to the Self and to notions of morality. As a result, the use of military means was articulated as, under certain circumstances, equivalent with peace, the protection of human rights, upholding international law and Germany's international integration. Indeed, under certain circumstances, it was the morally 'right' thing to use force. ${ }^{15}$

The way the project succeeded was because it clearly articulated a lack within the old way of doing things, created a broad chain of equivalent demands, identified a clear obstacle to be overcome, presented an empty signifier to identify with and, importantly, explicitly drew on sedimented discursive practices. To begin with, discourse participants clearly identified new conflicts as the reason for why contrary to original expectations, world peace did not materialize at the end of the Cold War. Moreover, advocates of Germany's international responsibility questioned the continued adequateness of strict military reticence as a means to achieve peace, in particular if the perpetrators of violence were unwilling to give in. This was essentially a moral dilemma: Although military force was commonly deemed immoral, relying on non-military means exclusively might prove inefficient and prolong violence, thus making it equally morally problematic. This was most

\footnotetext{
${ }^{15}$ At the same time, 'war' continues to be closely connected with the past and to this day is considered an immoral endeavor.
} 
clearly put by Foreign Minister Klaus Kinkel in a debate on 22 July 1992 who argued that the Bosnian war had

"visualized [...] that the traditional instruments of our peace and security policy do not suffice. $[\ldots][\mathrm{I}] \mathrm{t}$ unfortunately proves to be true that those responsible for violence and aggression only react when it is demonstrated to them that their criminal action leads to a reaction by the international community" (Kinkel, 12/101, 22 July 1992: 8609, emphasis added).

Here, Kinkel argued that the old way of doing things (i.e., relying on non-military means exclusively) had failed, practically and morally. Continued aggression sometimes required a military reaction, and as a consequence, Germany needed, as Kinkel argued in a different context, to find a "new [...] consensus" on peace operations (Kinkel, 12/151, 21 April 1993: 12925). Thus, the threat and use of force was rearticulated in such a way that a previously contrary relation to peace and morality became equivalent (as compatible or going hand in hand), at least under certain circumstances. Thus, in the context of the Gulf War, Chancellor Kohl argued that "our own history teaches" us "that right must never give way to wrong" and that "aggressors have to be confronted in good time" (Kohl, 12/2, 14 January 1991: 22).

The normative aspect is much more clearly visible in later debates in the run-up to Operation Allied Force, in which the threat and use of military force was articulated as a matter of moral responsibility. For instance, in October 1998 Defense Minister Volker Rühe argued that:

“[t]here are enough examples in history that show: it can be immoral to deploy soldiers; there are however also other situations in which one has to say that it is profoundly immoral not to deploy soldiers, if it is the only chance to stop war and massacre" (Rühe, 13/248, 16 October 1998: 23134). 
On the flipside, strict pacifism was rearticulated as a morally problematic position.

For instance, in 1993 CDU/CSU MP Christian Schmidt argued that military reticence, if taken to the extreme, could amount to "genocidal pacifism" (Schwarz, 12/151, 21 April 1993: 12971). ${ }^{16}$

Importantly, and somewhat paradoxically, advocates of German responsibility even referred to antimilitarism to make the case for participation in military operations, thus drawing on the still widespread notion that military reticence was in principle morally desirable. This usually follows a common pattern. Supporters of military operations would first argue that military means should never be anything but a means of last resort for moral reasons, only to subsequently claim that all other means had in fact been exhausted, which only left a binary choice between 'doing nothing' and military operations. For example, in a debate about Operation Deny Flight, Foreign Minister Kinkel expressly stated that "[m]ilitary coercion may always only be the very last resort in the keeping of peace" (Kinkel, 12/151, 21 April 1993: 12928) but continued to point out that "only armed force - and not peace marches - have put an end to Hitler's crimes in 1945. [...] Can we close our eyes to [the fact] that the murder in this world [...] can precisely not be switched off with words alone?" (Kinkel, 12/151, 21 April 1993: 12928). ${ }^{17}$ This is also an example for how arguments draw on gender discourse for legitimacy, according to which masculine coded characteristics like activity or strength are to be preferred over feminine ones like passivity and weakness (see Hooper 2001; Peterson 2010).

\footnotetext{
${ }^{16}$ On the delegitimation of pacifist positions more generally, see Jackson (2017).

${ }^{17}$ See also the discussion in Zehfuss (2007) that highlights the construction of equivalence between the Bundeswehr and the Allied forces during the Second World War.
} 
All the while policymakers were demanding that the use of military violence be made possible, they also insisted that "German foreign policy was and also in the future remains peace policy" (Kinkel, 12/151, 21 April 1993: 12929) and that the Bundeswehr's only purpose remained to serve peace. To give but one example, in a debate about Operation Maritime Monitor, Foreign Minister Kinkel insisted that German soldiers "all together and entirely without qualification serve peace and nothing else. [...] No one should insinuate that the Bundeswehr and the soldiers of the Bundeswehr serve any other goal and purpose than the law and peace" (Kinkel, 12/101, 22 July 1992: 8619). ${ }^{18}$

Moreover, military operations were said not only to contribute to peace but also to ensure Germany's continued adherence to multilateralism and Western integration, its support for international organizations and international law (e.g., Kinkel, 12/101, 22 July 1992). This was closely linked to arguments about the proper (moral) lessons of the past (see Zehfuss 2007). Instead of strict military reticence being the adequate lesson of Germany's own past, coalition members stressed the need to above all avoid a German special path. For example, Foreign Minister Kinkel claimed that "one lesson from this [Germany's] history can really only be: Never again sheer off from the community of Western peoples, never again special paths, [not even] that of moral know-it-all attitude and of ethics of conviction" (Kinkel, 12/151, 21 April 1993: 12928).

Refusal to participate in peace operations risked a number of negative consequences, including becoming "incapable to function as an alliance partner" (bündnisunfähig) and ultimately the country's "isolation [...] in the community of states" (Kinkel, 12/151, 21 April

\footnotetext{
18 Similar arguments were taken up by the SPD/Green government which assumed power in 1998 (e.g., Schröder, 14/3, 10 November 1998: 64).
} 
1993: 12928, 12929). "Alliance solidarity" (Bündnissolidarität), the capability to function as an alliance partner (Bündnisfähigkeit) and, "reliability" more generally were prominent demands in the debates about the Yugoslav wars (for instance Glos, 13/48, 30 June 1995: 3984; Kinkel, 13/48, 30 June 1995: 3957; Rühe, 13/87, 9 February 1996: 7679; Volmer, 13/248, 16 October 1998: 23151; Kinkel, 13/248, 16 October 1998: 23129). Overall, the project forged a broad equivalential chain out of different demands, thus broadening its appeal.

It is important to point out once more that arguments in favor of military operations draw on deeply sedimented gendered and racialized discourses for legitimacy, for example through demands for sobriety (i.e., emotional detachment) in decision-making (e.g., Waigel, 11/24, 10 September 1987: 1584) or the construction of the 'local' population as in need of Western help. In addition, the "logic of masculinist protection" (Young 2003) features prominently in the German security discourse, invoking the figure of the soldier as a selfless hero to delegitimize criticism of security policy in general and military operations specifically (e.g., Rühe, 13/248, 16 October 1998: 23134).

The hegemonic project also presented a clear way forward, a universal remedy to overcome that lack of peace. This function was fulfilled by the demand for Germany to accept its "international responsibility" (e.g., Stoltenberg, 12/27, 5 June 1991: 2033; Kolbow, 12/70, 16 January 1992: 5884; Wollenberger, 12/101, 22 July 1992: 8630). ${ }^{19}$ By doing so, Germany could continue to be part of the West and the international community more broadly, help people in need, continue to respect the lessons of history and, broadly, 'do the right thing'. That is, (the acceptance of its) international responsibility after unification, i.e., participation in multinational military operations, was articulated as an empty signifier.

\footnotetext{
19 The importance of responsibility has been discussed by a number of authors (see Crossley-Frolick 2017; Schwab-Trapp 2002; Geis and Pfeifer 2017; Stahl 2017; Stengel forthcoming).
} 
What made responsibility particularly effective in this regard was its remaining particular content. No empty signifier is ever completely empty, and because of its elevated position the empty signifier influences the overall character of the hegemonic project it symbolizes (Thomassen 2005). In the case of responsibility what matters most is the strong notion of duty with which responsibility (Verantwortung) is associated. Articulating military missions in terms of responsibility suggests that it is not about choice. Duties are not a matter of a decision between two equally valid (contingent) options but an external demand that not fulfilling comes at the risk of being seen as irresponsible and unreliable. As a consequence, the language of responsibility itself delegitimizes criticism due to sedimented meanings.

Thus, the German out-of-area debate provides an example of how the relationship between ethics and war, between notions of the moral good and the use of military force became transformed as a result of discursive hegemony. While the use of force was commonly deemed morally unacceptable (as well as illegal) during the Cold War, at the end of the 1990s it had become, while still considered in principle undesirable, recognized as an unavoidable instrument of German peace policy. Indeed, a fundamental opposition to the use of force was now deemed morally reprehensible. By the end of the 1990s, all political parties except Die Linke had joined this new out-of-area consensus.

\section{Conclusion}

Laclau's notion of hegemony provides a conception of how the connection between the ethical, that unattainable universal, and morality, the contingent content that seeks to symbolically represent the ethical, are connected. It directs our attention to the discursive struggles by which particularities seek to temporarily establish themselves as universals. From such a perspective, the reason why the ethics of war is doomed to fail is that there is an 
irresolvable gap between individual representations (e.g., ethical rules) and reality in its infinite complexity ('the good'), between discourse and the discursive (Nabers 2015). This gap cannot be bridged, and this is the source of the problem why attempts to reign in war through the formulation of ever better ethical principles can only fail. Like Zehfuss, a discourse theoretical approach directs our attention to the "precariousness of our ethical claims" (Zehfuss 2018, 50). At the same time, it complements Zehfuss's approach by providing a theoretical framework that can explain how new notions of what is morally 'right' become widely accepted, including in the context of war.

\section{References}

Baumann, Rainer, and Gunther Hellmann. 2001. "Germany and the Use of Military Force: "Total War", the "Culture of Restraint" and the Quest for Normality." German Politics $10(1): 61-82$.

Berger, Thomas U. 1998. Cultures of Antimilitarism: National Security in Germany and Japan. Baltimore, MD: Johns Hopkins University Press.

Chandra, Uday. 2013. "The Case for a Postcolonial Approach to the Study of Politics." New Political Science 35 (3):479-91.

Critchley, Simon. 2004. "Is There a Normative Deficit in the Theory of Hegemony?" In Laclau: A Critical Reader, edited by Simon Critchley and Oliver Marchart, 113-22. London \& New York: Routledge.

Crossley-Frolick, Katy A. 2017. "Revisiting and Reimagining the Notion of Responsibility in German Foreign Policy." International Studies Perspectives 18 (4):443-64.

Dalgaard-Nielsen, Anja. 2006. Germany, Pacifism and Peace Enforcement. Manchester: Manchester University Press.

Doty, Roxanne Lynn. 1996. Imperial Encounters: The Politics of Representation in North-South Relations. Minneapolis, MN: University of Minnesota Press.

Eberle, Jakub. 2019. Discourse and Affect in Foreign Policy: Germany and the Iraq War. New York: Routledge.

Eckstein, Harry. 1975. "Case Study and Theory in Political Science." In Handbook of Political Science, Vol. 7: Strategies of Inquiry, edited by Fred I. Greenstein and Nelson W. Polsby, 79-137. Reading, MA: Addison-Wesley.

Geis, Anna, and Hanna Pfeifer. 2017. "Deutsche Verantwortung in der „Mitte der Gesellschaft" aushandeln? Über Politisierung und Entpolitisierung der deutschen Außenpolitik." In Politik und Verantwortung: Analysen zum Wandel politischer Entscheidungs- und Rechtfertigungspraktiken, edited by Christopher Daase, Julian Junk, Stefan Kroll and Valentin Rauer, 218-43. Baden-Baden: Nomos.

Harnisch, Sebastian, and Hanns W. Maull. 2001, eds. Germany as a Civilian Power? The Foreign Policy of the Berlin Republic. Manchester: Manchester University Press. 
Herschinger, Eva. 2011. Constructing Global Enemies: Hegemony and Identity in International Discourses on Terrorism and Drug Prohibition. London \& New York: Routledge.

Hooper, Charlotte. 2001. Manly States: Masculinities, International Relations, and Gender Politics. New York: Columbia University Press.

Hutchings, Kimberly. 2008. "Making Sense of Masculinity and War." Men and Masculinities $10(4): 389-404$.

Inayatullah, Naeem. 2014. "Why Do Some People Think They Know What Is Good for Others?" In Global Politics: A New Introduction, edited by Jenny Edkins and Maja Zehfuss, 450-71. London \& New York: Routledge.

Jackson, Richard. 2017. "Pacifism: The Anatomy of a Subjugated Knowledge." Critical Studies on Security 6 (2):160-75.

Laclau, Ernesto. 1990. "New Reflections on the Revolution of Our Time." In New Reflections on the Revolution of Our Time, edited by Ernesto Laclau, 3-85. London: Verso.

- - - . 1994. "Introduction." In The Making of Political Identities, edited by Ernesto Laclau, 110. London \& New York: Verso.

- - - 1996. "Why Do Empty Signifiers Matter to Politics?" In Emancipation(s), edited by Ernesto Laclau, 36-46. London: Verso.

- - - 2000. "Identity and Hegemony: The Role of Universality in the Constitution of Political Logics." In Contingency, Hegemony, Universality: Contemporary Dialogues on the Left, edited by Judith Butler, Ernesto Laclau and Slavoj Žižek, 44-89. London \& New York: Verso.

- - - 2004. "An ethics of militant engagement." In Think Again: Alain Badiou and the Future of Philosophy, edited by Peter Hallward, 120-37. London: Continuum.

- - - 2005. On Populist Reason. New York: Verso.

- - - . 2012. "Reply." Cultural Studies 26 (2-3):391-415.

- - - 2014a. "The Death and Resurrection of the Theory of Ideology." In The Rhetorical Foundations of Society, edited by Ernesto Laclau, 11-36. London: Verso.

- - - 2014b. "An Ethics of Militant Engagement." In The Rhetorical Foundations of Society, edited by Ernesto Laclau, 181-206. London: Verso.

- - - 2014c. "Ethics, Normativity and the Heteronomy of the Law." In The Rhetorical Foundations of Society, edited by Ernesto Laclau, 127-37. London: Verso.

- - - . 2014d. "On the Names of God." In The Rhetorical Foundations of Society, edited by Ernesto Laclau, 37-51. London: Verso.

- - - ed. 2014e. The Rhetorical Foundations of Society. London: Verso.

Laclau, Ernesto, and Chantal Mouffe. 2001. Hegemony and Socialist Strategy: Towards a Radical Democratic Politics. 2nd ed. London: Verso.

Longhurst, Kerry. 2004. Germany and the Use of Force. Manchester: Manchester University Press.

Maull, Hanns W. 2007. "Deutschland als Zivilmacht." In Handbuch zur deutschen Außenpolitik, edited by Gunther Hellmann, Reinhard Wolf and Siegmar Schmidt, 73-84. Wiesbaden: VS Verlag für Sozialwissenschaften.

Nabers, Dirk. 2015. A Poststructuralist Discourse Theory of Global Politics. Basingstoke: Palgrave Macmillan.

Norval, Aletta J. 2004. "Hegemony after Deconstruction: The Consequences of Undecidability." Journal of Political Ideologies 9 (2):139-57.

Nuñez-Mietz, Fernando G. 2018. "Legalization and the Legitimation of the Use of Force: Revisiting Kosovo." International Organization 72 (3):725-57. 
Peterson, V. Spike. 2010. "Gendered Identities, Ideologies, and Practices in the Context of War and Militarism." In Gender, War, and Militarism: Feminist Perspectives, edited by Laura Sjoberg and Sandra Via, 17-29. Santa Barbara, CA: ABC-CLIO.

Philippi, Nina. 1997. Bundeswehr-Auslandseinsätze als außen- und sicherheitspolitisches Problem des geeinten Deutschlands. Frankfurt am Main: Peter Lang.

Renner, Judith. 2013. Discourse, Normative Change and the Quest for Reconciliation in Global Politics. Manchester: Manchester University Press.

Rothe, Delf. 2015. Securitizing Global Warming: A Climate of Complexity. London \& New York: Routledge.

Sayre-McCord, Geoff. 2012. "Metaethics." In The Stanford Encyclopedia of Philosophy (Spring 2012 Edition), edited by Edward N. Zalta. Stanford: Stanford University.

Schwab-Trapp, Michael. 2002. Kriegsdiskurse. Die politische Kultur des Krieges im Wandel 19911999. Opladen: Leske + Budrich.

Solomon, Ty. 2014. The Politics of Subjectivity in American Foreign Policy Discourses. Ann Arbor, MI: University of Michigan Press.

Stahl, Bernhard. 2017. "Verantwortung - welche Verantwortung? Der deutsche Verantwortungsdiskurs und die Waffenlieferungen an die Peschmerga." Zeitschrift für Politikwissenschaft 27 (4):437-71.

Stengel, Frank A. Forthcoming. The Politics of Military Force: Antimilitarism, Ideational Change and Post-War German Security Discourse. Ann Arbor, MI: University of Michigan Press.

Stengel, Frank A. 2019. "Securitization as Discursive (Re)Articulation: Explaining the Relative Effectiveness of Threat Construction." New Political Science 41 (2):294-312.

Stengel, Frank A., and Dirk Nabers. 2019. "The Contribution of Laclau's Discourse Theory to International Relations and International Political Economy: Introduction to the Symposium." New Political Science 41 (2): 248-262.

Thomas, Claire. 2011. "Why don't we talk about 'violence' in International Relations?" Review of International Studies 37 (4):1815-36.

Thomassen, Lasse. 2005. "Antagonism, Hegemony and Ideology after Heterogeneity." Journal of Political Ideologies 10 (3):289-309.

Young, Iris Marion. 2003. "The Logic of Masculinist Protection: Reflections on the Current Security State." Signs: Journal of Women in Culture \& Society 29 (1):1-25.

Zehfuss, Maja. 2002. Constructivism in International Relations: The Politics of Reality. Cambridge: Cambridge University Press.

- - - 2007. Wounds of Memory: The Politics of War in Germany. Cambridge: Cambridge University Press.

- - - 2018. War and the Politics of Ethics. Oxford: Oxford University Press. 